\title{
Monkey see, monkey do - a comparison of the attitudes of top and purchasing managers to corruption in business
}

\author{
L. Pitt \\ Department of Marketing, School of Business, Western Australian College, Perth, Western Australia \\ D. Nel* and P. de Wit \\ Department of Business Economics, University of Pretoria, Hillcrest, Pretoria, 0001 Republic of South Africa \\ Received 28 April 1988
}

\begin{abstract}
This article describes a comparative survey of the attitudes of top and purchasing managers regarding the extent to which their attitudes towards corrupt and possibly corrupt business behaviour differs. The extent of perceived peer group participation in deviant activities is also measured. The results of the research indicate that while there is little or no difference between the groups regarding attitude and perceived participation measures, there is a marked difference between the attitudes for both groups and the perceived participation of their peers. The need for top management action on policy in this regard is emphasized.
\end{abstract}

Hierdie artikel beskryf 'n vergelykende opname van die houdings van top- en aankoopbestuurders aangaande die mate van verskil in houdings met betrekking tot korrupsie en moontlike korrupte sakepraktyke. Die omvang van waargenome deelname ten opsigte van afwykende aktiwiteite is ook gemeet. Die resultate van die navorsing dui daarop dat daar min of geen verskil is tussen die groepe se houdings en waargenome deelname nie. Daar is wel ' $n$ aansienlike verskil tussen die houding van beide groepe en die waargenome deelname van portuurgroepe. Die behoefte aan beleidstelling deur topbestuur ten opsigte van die probleem word beklemtoon.

" To whom correspondence should be addressed

People would generally agree that an assortment of ethical precepts governs the actions of managers, both in public and in private sectors. Yet, the media reports with distressing regularity of contraventions of the Prevention of Corruption Act, No. 6 of 1958 (various issues of The Star, March and April 1983). While political and business leaders plead for stricter and sterner action, concepts such as 'connection', 'favour', 'token of appreciation' and 'privileged position' have assumed new interpretations. Even the Judaic and Christian Bibles refer to corruption (see for example Ecclesiastes, Chapter 7, Verse 7). Corruption exists to some extent in (and is, of course, viewed differently by) all cultures and in all countries. The Ottoman Empire of the 19th century existed on corruption and bribery, and companies doing business in Mexico have become quickly acquainted with 'mordida' the 'bite'. Even today many governments would probably fall if corruption were eradicated overnight, yet eradication in a total sense is probably a pipe dream. The corrupt person has been defined as one who uses (or is it perhaps abuses?) the position of authority entrusted to him to his own selfish advantage, enrichment or aggrandisement to the disadvantage of his organization, and ultimately to society as a whole (Pitt \& Abratt, 1986).

Among the areas of business which have been particularly prone to issues concerning ethics have been marketing (Ferrell \& Gresham, 1985) and purchasing (Rudelius \& Bucholz, 1979). As that functional domain of business which exercises considerable influence in the selection of suppliers, granting of orders and often the delineation of specifications, purchasing and purchasing managers in most organizations are confronted daily with ethical issues. Purchasing managers may have a lot of power which they are expected to exercise to keep costs down. However, their very use of this faculty confronts them with ethical issues they cannot always answer, often they do not care to. Frequently the purchasing job demands flexibility and when ethical guidelines are put in writing this flexibility may be sacrificed. Yet, in reality, it is top management which should be laying down policy in these areas. Weaver \& Ferrell (1977) have suggested the necessity for top management to assume at least part of the responsibility for the ethical conduct within their organizations.

This paper reports the results of a study concerning a comparison of attitudes towards corruption, (and possibly corrupt) business practices between top management and purchasing managers.

\section{Deviant behaviour - a question of attitudes?}

Deviant behaviour is often the result of, and is exacerbated by, attitudes towards that behaviour. If shoplifting, for example, is seen really as 'taking something', rather than theft, then it is clear that it will not be viewed by the perpetrator (or his peers) as a serious criminal offence. Similarly, if the attitude towards accepting a bribe is one of 'everyone's doing it' or 'I deserve it', or 'It's a perk of the job', then it can be assumed that the corrupt action will be a part of business life.

Behaviour of superiors and peers is also seen by Ferrell \& Gresham (1985) in their model as a critical factor influencing ethical/unethical behaviour, and for this reason it is deemed important to contrast the attitudes of top managers and purchasing managers. The 
effect of the perceived behaviour of superiors on individual action has been well researched (Brenner \& Molander, 1977; Newstrom \& Ruch, 1975). It has also been reported that managers perceive peer group participation in potentially corrupt practices as being disproportionate to their own attitudes towards deviant situations (Pitt \& Abratt, 1986). Finally, the opportunity(ies) available to individuals to engage in unethical behaviour is a strong causative factor resulting from a favourable set of conditions to limit barriers, or provide rewards (Ferrell \& Gresham, 1985). It is obvious that some jobs within an organization, and also within different types of organizations, lend themselves more easily to, or offer more opportunities for, unethical behaviour. As has been indicated, the marketing and purchasing functions tend to be visible in this regard, and obviously the activities and attitudes of top management will permeate the organization.

\section{Attitude measurement and the technique of perceived participation}

The measurement of attitudes towards deviant behaviour is compounded by a host of factors. In many instances the researcher finds it difficult and even impossible to measure attitudes and participation for one can scarcely hope to obtain honest answers from one who may by definition be dishonest (Pitt, 1982: 186). A number of researchers have employed the technique of perceived participation (Wilkes, 1978), also known as the Third-person Technique (Green \& Tull, 1978: 139-141; Lane \& Watson, 1975: 48-59). To overcome this problem, respondents are asked to what extent members of their peer group participate in the activities in question. The researcher is thus able to gain an indication of overall group participation (including that of the respondents).

\section{Methodology}

The methodology used in this study is based on that suggested by Pitt \& Abratt (1986) and uses essentially the same scenarios employed in the aforementioned pilot study. These cases in the form of scenarios present a series of behavioural situations which could be construed as being deviant, dishonest, or corrupt to respondents. Respondents are then required to indicate the extent to which:

1. They approve/disapprove of the situation.

2. Their friends or colleagues would act in the manner described.

3. The appropriate action to be taken by management/ the organization should they become aware of the situation.

The scenarios used in this study are presented in Table 1.

Questionnaires presenting these scenarios, with instruction on their completion were mailed to the top and purchasing managers of 500 companies selected by means of a stratified sample requiring employment exceeding 500, and electrical power consumption exceeding $150000 \mathrm{~kW}$ per hour per month. The response rate was as follows: Top management, $163(32,6 \%)$ and purchasing management, $146(29,2 \%)$.

\section{Table 1 Scenarios}

1. A purchasing manager is offered the sum of R5000 on condition that he awards a large contract to a certain company. He accepts the offer.

2. A project engineer awards a sizable tender. A week later the company invites him on an all expenses-paid shooting trip to their private game reserve. He accepts their offer.

3. Members of a company negotiating team accept a potential suppliers invitation to lunch

4. On condition that he let them know of rival tender prices, a tender official is offered the opportunity of having his home carpeted throughout. He supplies every price tendered.

5. A company official receives a bottle of whiskey from a supplier as a Christmas gift. He phones to say thanks.

6. Shortly after awarding a large contract, a company official and his son are invited to join the suppliers at their private box at a major rugby match. They accept the offer.

7. Shortly before the announcement of a large new tender, one of the tender officials has a sheep and a case of whiskey delivered to his home by one of the parties. He accepts the gifts.

8. A geologist working for a major mining group gains important information regarding the development of a new reef. He immediately buys 1000 company shares.

9. A branch manager receives a voucher for a weekend's stay at a holiday resort from a supplier, as a birthday present. His secretary telephones his thanks.

10. A senior manager siphons petrol from his company car and transfers it to his wife's car for her shopping.

11. The marketing manager and his wife entertain friends at a top restaurant. He books the bill to his expense account...'dined with potential customers'

12. A company is known to be in the market for twenty heavy vehicles. One of the potential suppliers invites the specification engineer on an overseas trip so that he can 'visit their highly sophisticated facilities'. He accepts the offer.

13. The financial manager knows that the next company report will be the best yet. He instructs his broker to purchase R10000's worth of shares on his behalf.

14. On returning from a visit to a supplier a buyer finds his car boot filled with groceries. He does nothing about this.

15. On arrival at his hotel in another city, a company purchasing manager receives a phone call from the secretary of a supplier's sales manager. Her boss, she says, has instructed her to take him out for a 'night on the town'. He accepts her invitation. 
The following broad hypotheses were formulated:

H1 There is no difference between top and purchasing managers regarding their overall disapproval of potentially corrupt business situations.

H2 There is no difference between top and purchasing managers regarding the participation of peer group members' participation in these activities.

H3 There is no difference between either group's approval/disapproval of peer group members in these activities. Put more simply: If a respondent totally disapproves of a scenario, it is unlikely that his friends and colleagues would ever participate in that activity).

The findings of the study are now presented and discussed and the hypotheses tested.

\section{Results and Discussion}

Overall approval/disapproval of scenarios

The first question asked of respondents with regard to the scenarios put before them was: Referring to the situations presented, indicate how right or wrong you feel each to be, using a scale of from 1 = definitely wrong, through $2=$ wrong, and $3=$ understandable, to 4 $=$ not wrong at all. The responses for both groups are presented in Table 2.

Mean scores and standard deviations were calculated for each group with regard to each of the scenarios and a mean of means for the 15 situations for each group.

Table 2 Approval/Disapproval of scenarios - top- and purchasing managers (How 'wrong' do you feel the situation to be, on a four-point scale where $1=$ definitely wrong; $4=$ not wrong at all)

\begin{tabular}{|c|c|c|c|c|}
\hline \multirow[b]{2}{*}{ Scenario } & \multicolumn{2}{|c|}{ Top managers } & \multicolumn{2}{|c|}{ Purchasing managers } \\
\hline & Mean & $S D$ & Mean & $S D$ \\
\hline 1. Bribe & 1,030 & 0,172 & 1,020 & 0,248 \\
\hline 2. Hunting trip & 2,159 & 0,968 & 2,116 & 0,979 \\
\hline 3. Free lunch & $3,190^{1}$ & 0,782 & $2,945^{1}$ & 1,001 \\
\hline $\begin{array}{l}\text { 4. Competitor } \\
\text { information }\end{array}$ & 1,030 & 0,205 & 1,020 & 0,184 \\
\hline 5. Christmas gift & 3,552 & 0,630 & 3,575 & 0,683 \\
\hline 6. Sporting event & 3,349 & 0,661 & 3,363 & 0,804 \\
\hline 7. Large gifts & 1,245 & 0,498 & 1,273 & 0,569 \\
\hline $\begin{array}{l}\text { 8. Geologist } \\
\text { knowledge }\end{array}$ & $2,208^{1}$ & 0,965 & $2,541^{1}$ & 0,962 \\
\hline 9. Free weekend & 2,018 & 0,885 & 1,931 & 0,914 \\
\hline 10. Fuel siphoning & 1,085 & 0,281 & 1,130 & 0,443 \\
\hline $\begin{array}{l}\text { 11. False expense } \\
\text { claims }\end{array}$ & 1,288 & 0,517 & 1,356 & 0,671 \\
\hline 12. Free overseas trip & 2,312 & 1,027 & 2,280 & 1,061 \\
\hline 13. Insider trading & $1,963^{1}$ & 0,915 & $2,239^{1}$ & 0,991 \\
\hline 14. Free groceries & 1,423 & 0,665 & 1,383 & 0,646 \\
\hline 15. Secretary & 1,957 & 0,863 & 1,958 & 0,908 \\
\hline Overall mean & 1,987 & & 2,008 & \\
\hline
\end{tabular}

1 Significant difference, $p<0,05$
The fact that the means of means for the two groups do not differ significantly leads us to accept $\mathrm{H} 1$, in other words there is no difference between top and purchasing managers with regard to their overall disapproval of the 15 scenarios presented. Stated more generally, top management and purchasing management tend to deem corrupt and potentially corrupt situations in business in the same light. It is, however, apparent from Table 2 that there is a difference within the groups with regard to three scenarios, namely the lunch situation (scenario 3), geologist knowledge (scenario 8), and insider trading (scenario 13 ) at the $95 \%$ confidence level. Referring to scenario 3, do top managers view the invitation to lunch as being even less improper than do purchasing management? Is this perhaps because top management (and also of course, marketing and sales people) have resorted to the lunch invitation as a means of gaining buyer attention, a device for prolonging the sales call, or a way of saying thank you for an order? Do purchasing managers view the lunch invitation at best as purloining of their time, and at worst an incommensurate attempt at a bribe? With regard to situations 8 (geologist knowledge) and 13 (insider trading), significant differences reveal that top managers believe the activities to be more wrong than purchasing managers. While an attempt at explication of this may be mere conjecture, the most obvious one is that top managers are probably more aware of the consequences of these actions, and they may be more vague and abstract contemplations for purchasing managers.

Table 3 Extent of perceived peer group participation top managers and purchasing managers (How often would your friends/colleagues behave as described. 1 $=$ never; $4=$ most of the time)

\begin{tabular}{|c|c|c|c|c|}
\hline \multirow[b]{2}{*}{ Scenario } & \multicolumn{2}{|c|}{ Top managers } & \multicolumn{2}{|c|}{ Purchasing managers } \\
\hline & Mean & $S D$ & Mean & $S D$ \\
\hline 1. Bribe & 1,515 & 0,811 & 1,554 & 0,947 \\
\hline 2. Hunting trip & 2,374 & 0,910 & 2,383 & 0,948 \\
\hline 3. Free lunch & $3,331^{1}$ & 0,729 & $3,136^{1}$ & 0,958 \\
\hline $\begin{array}{l}\text { 4. Competitor } \\
\text { information }\end{array}$ & 1,441 & 0,720 & 1,493 & 0,840 \\
\hline 5. Christmas gift & 3,576 & 0,683 & 3,486 & 0,798 \\
\hline 6. Sporting event & 3,171 & 0,725 & 3,041 & 0,908 \\
\hline 7. Large gifts & 1,705 & 0,830 & 1,691 & 0,906 \\
\hline 8. Geologist knowledge & 2,361 & 1,017 & 2,383 & 1,012 \\
\hline 9. Free weekend & 2,110 & 0,916 & 2,205 & 0,946 \\
\hline 10. Fuel siphoning & 1,705 & 0,867 & 1,767 & 0,879 \\
\hline 11. False expense claims & 2,257 & 0,857 & 2,417 & 1,001 \\
\hline 12. Free overseas trip & 2,239 & 0,948 & 2,150 & 0,956 \\
\hline 13. Insider trading & 2,147 & 1,007 & 2,226 & 1,022 \\
\hline 14. Free groceries & 1,760 & 0,894 & 1,856 & 0,939 \\
\hline 15. Secretary & 2,030 & 0,863 & 2,184 & 0,989 \\
\hline Overall mean & 2,248 & & 2,264 & \\
\hline
\end{tabular}

' Significant difference, $p<0,05$ 


\section{Perceived peer group participation}

The technique of perceived participation or third-person interviewing was used to gauge the extent to which respondents were of the opinion that members of their peer group participated in the activities described. Once more a four-point scale was used ranging from $1=$ never, through $2=$ seldom, and $3=$ once in a while, to 4 $=$ most of the time. A comparison of top and purchasing managers' perceptions of participation by colleagues and friends in the scenarios presented is made in Table 3 and both means and standard deviations for each scenario are shown for each of the two groups.

The means of means for the two groups are not significantly different and once again $\mathrm{H} 2$ cannot be rejected. Otherwise stated, there is no significant degree of difference between the extent to which top management are of the opinion that peer group members participate in the activities described and the perceptions of purchasing management. A significant difference does exist between the means of one individual situation for both groups. Again, this is situation 3, the lunch scenario. Simply stated, top managers are of the opinion that their peer group members would accept the lunch invitation to a somewhat greater extent than purchasing management are of the opinion that friends and colleagues would assent to it.

\section{A comparison between net approval and perceived participation}

A number of studies which have considered approval/ disapproval of potentially deviant situations and perceived peer group participation have made the interesting observation that perceived participation inevitably exceeds net disapproval. This has also been borne out in earlier pilot studies of managerial attitudes towards corruption (Pitt \& Abratt, 1986). While most managers believe for example that accepting a bribe is totally wrong, far fewer are of the opinion that their friends and colleagues would never accept a pay-off (Pitt \& Abratt, 1986).

Table 4 combines Tables 2 and 3 and from this table a comparison of the extent of approval/disapproval of each group for each situation and the degree of perceived peer group participation can be made.

With regard to top managers it is clearly evident that there is a significant difference between what top managers believe is wrong and what their friends and colleagues do. Hence, $\mathrm{H} 3$ (for top managers) is rejected. This is true for the means of means but perhaps more disconcerting is the fact that most of the significant differences here tend to be on the more serious situations accepting a bribe, disclosing tender information, receiving overly extravagant gifts, siphoning petrol, fiddling an expense account, and accepting inordinate free groceries. How might the

Table 4 Degree of approval/disapproval of scenarios by top- and purchasing managers, and degree of perceived peer group participation

\begin{tabular}{|c|c|c|c|c|c|c|c|c|}
\hline \multirow[b]{3}{*}{ Scenario } & \multicolumn{4}{|c|}{ Top managers } & \multicolumn{4}{|c|}{ Purchasing managers } \\
\hline & \multicolumn{2}{|c|}{ Own beliefs } & \multicolumn{2}{|c|}{ Peer group } & \multicolumn{2}{|c|}{ Own beliefs } & \multicolumn{2}{|c|}{ Peer group } \\
\hline & $\bar{x}$ & $S D$ & $\bar{x}$ & $S D$ & $\overline{\boldsymbol{X}}$ & $S D$ & $\bar{X}$ & $S D$ \\
\hline 1. Bribe & 1,030 & 0,172 & 1,515 & 0,811 & 1,020 & 0,248 & 1,554 & 0,947 \\
\hline 2. Hunting trip & 2,159 & 0,968 & 2,374 & 0,910 & 2,116 & 0,979 & 2,383 & 0,948 \\
\hline 3. Lunch & 3,190 & 0,782 & 3,331 & 0,729 & 2,945 & 1,001 & 3,136 & 0,958 \\
\hline $\begin{array}{l}\text { 4. Competitor } \\
\text { information }\end{array}$ & 1,030 & 0,205 & 1,441 & 0,720 & 1,020 & 0,184 & 1,493 & 0,840 \\
\hline 5. Christmas gift & 3,552 & 0,630 & 3,576 & 0,683 & 3,573 & 0,683 & 3,486 & 0,798 \\
\hline 6. Sporting event & 3,349 & 0,661 & 3,171 & 0,725 & 3,363 & 0,804 & 3,041 & 0,908 \\
\hline 7. Large gifts & 1,245 & 0,498 & 1,705 & 0,830 & 1,273 & 0,569 & 1,691 & 0,906 \\
\hline 8. Geologist knowledge & 2,208 & 0,965 & 2,361 & 1,017 & 2,541 & 0,962 & 2,383 & 1,012 \\
\hline 9. Free weekend & 2,018 & 0,885 & 2,110 & 0,916 & 1,931 & 0,914 & 2,205 & 0,946 \\
\hline 10. Fuel siphon & 1,085 & 0,281 & 1,705 & 0,867 & 1,130 & 0,443 & 1,767 & 0,879 \\
\hline 11. False expense claims & 1,288 & 0,517 & 2,257 & 0,857 & 1,356 & 0,671 & 2,417 & 1,001 \\
\hline 12. Free overseas trip & 2,312 & 1,027 & 2,239 & 0,948 & 2,280 & 1,061 & 2,150 & 0,956 \\
\hline 13. Insider trading & 1,963 & 0,915 & 2,147 & 1,007 & 2,239 & 0,991 & 2,226 & 1,022 \\
\hline 14. Free groceries & 1,423 & 0,665 & 1,760 & 0,894 & 1,383 & 0,646 & 1,856 & 0,939 \\
\hline 15. Secretary & 1,957 & 0,863 & 2,030 & 0,863 & 1,958 & 0,908 & 2,184 & 0,989 \\
\hline Overall mean & 1,987 & & 2,248 & & 2,008 & & 2,264 & \\
\hline
\end{tabular}

Notes: 1. Means in bold numerals differ significantly at the $95 \%$ confidence interval 2. Overall means become significant at the 0,36 significance level for top managers and for purchasing managers at the
0,38 level of significance. 
innocuous invitation to a sports event be explicated? Mere conjecture might allege that members of the peer group might simply be less interested in the particular type of sport, for one notes that it is the only scenario, as regards top managers, on which significant difference occurs where degree of approval exceeds degree of perceived participation.

What is observed for top managers is amplified for purchasing managers as is evident from Table 4. In this instance there are only four scenarios where there is no significant difference between degree of approval/ disapproval and extent of perceived participation. Two of these situations are trivial, namely a free lunch and a nominal Christmas gift. Two (a free trip, and insider trading) are more severe. However, the Ferrell \& Gresham (1985) contingency framework emphasizes opportunity as an important determinant of unethical behaviour and the opportunity for purchasing managers to engage in these latter two activities may in most instances be severely limited. As regards scenario 8 , degree of approval again exceeds perceived participation for purchasing managers. Again the lack of opportunity for purchasing managers to engage in the geologist knowledge situation, could be the reason for the evidently low perceived participation in this activity.

\section{Are there any implications for corporate policy?}

Are top management the corruptors, and are purchasing managers the corrupted, and is this due to the lack of policy direction from top management? If this were so one may have expected differences between how the two groups felt about the situations presented, and perhaps even to the extent to which they were perceived to occur. In this study the hypotheses that these differences should not occur were accepted. There is no essential difference between purchasing managers and top managers with regard to the degree of perceived participation of their peer groups. However, if a situation is regarded as being undesirable, one would expect that it occurs very infrequently. This appears to be less than true for both samples of respondents to this study. While situations are judged to be deserving of disfavour, in many instances friends and colleagues are perceived to be notirregular participants. More disquieting is the fact that this is especially true for the more serious situations presented. Does this mean that the respondents to this study are fine, upstanding folk, while their peers are not? This phenomenon is certainly not new to this type of research (Newstrom \& Ruch, 1975: 34-36).

The incongruity in the findings such as those presented here is that of the discrepancy between self-reported demeanour and perceptions of the beliefs and behaviour of others (see Newstrom \& Ruch, 1975: 34-36). In all probability some (and possibly all) of the respondents are either basing their judgements on rumour and notion rather than on sincere observation and reality. Or are they willingly or unknowingly distorting the truth? Where does the truth lie? Is the reporting of own attitudes more accurate and frank than the revelations of peer group implication? Unfortunately, it is extremely difficult to say which. The need for austere corporate policy in this regard becomes painfully (and possibly expensively) obvious. These managers who view the scenarios as serious but still occurring may be the ones who will eventually say, 'But everybody's doing it', and start to participate themselves.

The fact that an organization's values should be (and generally are) reflections of the values of its top management has been well established in the literature (Steiner, 1969; Steiner, 1965; Jennings, 1971). Essentially, the values of top management - whatever they are - will be carried down to lower organizational levels. If top managers accept - and are seen to accept - large gifts from suppliers or other stakeholders, then we can realistically expect organization members at lower hierarchical levels to do the same. The fact that purchasing managers are most of ten at the 'receiving' is reiterated and can be taken more than literally. How they act ethically will almost certainly be a function of what they perceive the values of top management to be.

The results of this study show that there is little difference between top managers and purchasing managers with regard to their approval/disapproval of a series of potentially corrupt situations. This would be satisfactory were it not for the fact that the study also shows that for both groups, perceived peer group participation in potentially corruptive activities, in most instances, significantly exceeds disapproval. It would seem as if the values of top managers are indeed being reflected in the values of those at lower hierarchical levels. Unfortunately, one could come to the conclusion that for both groups, what they say is not always what they do. Perhaps value espoused are not enough, greater attention should be given to no-loopholes, written policy. Cursory studies (Pitt \& Abratt, 1986) have shown this to be severely lacking, and a hypothesis for future empirical research is that this is indeed so. Written ethics policy should not merely be an optional nicety today - it is an unavoidable issue, which demands action in all organizations.

\section{References}

Brenner, S.N. \& Molander, E.A. 1977. Is the ethics of business changing. Harv. Bus. Rev., vol. 55, Jan-Feb.

Ferrell, O.C. \& Gresham, L.G. 1985. A Contingency Framework for Understanding Ethical Decision-making in Marketing. J. Market., vol. 49.

Green, P.E. \& Tull, D.S. 1978. Research for Marketing Decisions. 4th Edition, Englewood Cliffs, New Jersey: Prentice Hall, Inc.

Jennings, E.E. 1971. Routes to the Executive Suite. New York: Alfred A. Knopf.

Lane, G.S. \& Watson, G.L. 1975. A Canadian replication of Mason Haire's 'Shopping List' Study. J. Acad. Market. Sci., Winter.

Newstrom, J.W. \& Ruch, W.A. 1975. The ethics of management and the management of ethics. $M S U$ Bus. Topics, vol. 23, Winter. 
Pitt, L.F. 1982. The attitudes of young people to consumer initiated fraud against business. S. Afr. J. Bus. Mgmt., vol. 13 , no. 4.

Pitt, L.F. \& Abratt, R. 1986. Corruption in Business. Are Management Attitudes Right? J. Bus. Ethics, vol. 5.

Rudelius, W. \& Buchholz, R.A. 1979. Ethical problems of purchasing managers. Harv. Bus. Rev., Mar-Apr.

Steiner, G.A. (Ed.) 1965. The Creative Organization. University of Chicago Press.
Steiner, G.A. 1969. Top Management Planning. New York: MacMillan Co.

The Star, 21 March 1983. Wraps off the rip-offs.

The Star, 23 March 1983. How businesses can dodge the graft. Weaver, K.M. \& Ferrell, O.C. 1977. The impact of corporate policy on reported ethical beliefs and behaviours of marketing practitioners. Contemporary Marketing Thought: Educators Proceedings, Series 41, American Marketing Association.

Wilkes, R.E. 1978. Fraudulent Behaviour by Consumers. J. Market., October. 